\title{
INCIDENCE OF HYDATIDIFORM MOLE IN SYRIAN IMMIGRANT WOMEN AND TURKISH WOMEN
}

\author{
SURIYELI GÖÇMEN VE TÜRK KADINLARINDA HIDATIFORM MOL INSIDANSI
}

\author{
Taşkın ERKINÜRESIN ${ }^{1}$, Hakan DEMIRCi² (D) \\ Bursa Provincial Health Directorate Health Sciences University, Bursa Higher Specialization Training and Research Hospital, 'Pathology, \\ ${ }^{2}$ Family Medicine, Bursa, Turkey
}

ORCID IDs of the authors: T.E. 0000-0003-1725-6590; H.D. 0000-0003-0434-4807

Cite this article as: Erkinuresin T, Demirci H. Incidence of hydatidiform mole in Syrian immigrant women and Turkish women. J Ist Faculty Med 2020;83(4):427-33. doi: 10.26650/IUITFD.2020.0001

\section{ABSTRACT}

Objective: Immigration may affect the incidence of hydatidiform mole (HM). In this study, we aim to compare Syrian immigrant and Turkish pregnant women in terms of HM due to abortion and termination of pregnancy.

Method: An analysis of 907 endometrial curettage materials due to abortion or termination of pregnancy between the years 20162018 were performed. These curettage materials were examined with routine histopathologic methods. Examination of the curettage materials was repeated by a pathologist to confirm the diagnosis.

Results: HM was diagnosed in 56 of 768 Turkish pregnant women (7.30\%) and it was diagnosed in 22 of 139 Syrian immigrant pregnant women (15.80\%). HM incidence in Syrian immigrant pregnant women was significantly higher (2.06 times) than in Turkish women $(p=0.001)$. The rate of Syrian pregnant women in the group aged 20 or younger was significantly higher than Turkish pregnant women $(p<0.001)$. The rate of Turkish pregnant women aged between 30-34 and older was high in the group.

Conclusions: The incidence of HM is higher in Syrian pregnant women. The main causes affecting the incidence of HM in Syrian immigrants are nationality and age. Migration, with all its components, may explain the difference in HM incidence between these two neighboring communities.

Keywords: Adolescent pregnancy, dilatation and curettage, histopathology, hydatidiform mole, Syrian refugee

\section{ÖZET}

Amaç: Göç hidatiform mol (HM) insidansını etkileyebilir. Bu çalışmada, küretaj uygulanan ve gebeliği sonlandırılan Suriyeli göçmen ve Türk gebe kadınların HM açısından karşılaştııılması amaçlanmıştır.

Yöntem: 2016-2018 yılları arasında küretaj uygulanan ve gebeliği sonlandırılan 907 endometriyal küretaj materyalinin analizi yapıldı. Bu küretaj materyalleri rutin histopatolojik yöntemlerle incelendi. Küretaj materyallerinin incelenmesi, tanıyı doğrulamak için bir patolog tarafından tekrarlandı.

Bulgular: HM, 768 Türk gebe kadından 56'sında (\%7.30) ve 139 Suriyeli göçmen gebe kadından 22'sinde $(\% 15,80)$ teşhis edildi. Suriyeli göçmen gebe kadınlarda HM insidansı Türk gebe kadınlara göre (2,06 kat) anlamlı derecede yüksekti $(p=0.001)$. Yirmi yaşından küçük olan gruptaki Suriyeli gebe kadınların oranı Türk gebe kadınlara göre anlamlı olarak daha yüksekti ( $p<0.001)$. Türk gebe kadınların oranı ise 30-34 yaş ve daha yaşlı olan grupta yüksekti.

Sonuç: Suriyeli göçmen gebe kadınlarda HM insidansı daha yüksektir. Suriyeli göçmenlerde HM insidansını etkileyen başlıca nedenler milliyet ve yaştır. Göçmenlik tüm bileşenleri ile bu iki komşu topluluk arasındaki HM insidansındaki farkı açıklayabilir.

Anahtar Kelimeler: Adolesan gebelik, dilatasyon ve küretaj, hidatiform mol, histopatoloji, Suriyeli göçmen

Corresponding author/iletişim kurulacak yazar: erkinuresin@hotmail.com

Submitted/Başvuru: 15.01.2020 • Revision Requested/Revizyon Talebi: 14.04.2020 •

Last Revision Received/Son Revizyon: 18.04.2020 • Accepted/Kabul: 29.06.2020 • Published Online/Online Yayın: 05.10.2020

(C)Telif Hakkı $2020 \mathrm{~J}$ Ist Faculty Med - Makale metnine jmed.istanbul.edu.tr web sayfasından ulaşılabilir.

(C) Copyright 2020 by J Ist Faculty Med - Available online at jmed.istanbul.edu.tr 


\section{INTRODUCTION}

There has been intense immigration towards Turkey from Syria since 2011 due to the ongoing conflict in Syria. The Ministry of Internal Affairs Directorate General of Migration Management declared that the total population of Syrian refugees in Turkey registered by their biometric data as of $8^{\text {th }}$ November 2018 is 3 million 594 thousand 232 (1). 1 million 950 thousand 182 of these refugees are male and 1 million 644 thousand 50 of them are female (1). Syrian refugees benefit from health services in our country free of charge. According to official records, 276 thousand 158 Syrian babies were born in Turkish hospitals from 2011, when Syrians first started to enter the country, until $11^{\text {th }}$ December 2017 (2).

Unintended pregnancy is of high incidence among the immigrant population. Termination of unintended pregnancy is legal until the $10^{\text {th }}$ week after conception. After 10 weeks of pregnancy, abortion can only be performed in case of fetal impairment. Abortion is performed in pregnant women with findings of hydatidiform mole (HM) existence based on their human Chorionic Gonadotropin ( $\mathrm{hCG}$ ) levels and ultrasonography examination (USG) during periodic pregnancy follow-ups. HM is one of the diseases caused by villous trophoblasts associated with pregnancy (3). The most benign disease among gestational trophoblastic diseases is HM (4). HM has two histological types, partial hydatidiform mole (PHM) and complete hydatidiform mole (CHM) (5). hCG levels of CHMs are usually over 100,000 mlU/mL and fetal heart sounds do not exist (6-9). hCG levels are over $100,000 \mathrm{mIU} / \mathrm{mL}$ in less than $10 \%$ of PHMs (10-12).

HM prevalence varies throughout the world and occurs between 0.3 and 2.0 in one thousand pregnancies $(5,13$ 15). HM prevalence in curettage materials due to abortion or termination of pregnancy varies between $2.2 \%$ and $6.9 \%(3,12,27)$. There is proof that the incidence of $\mathrm{HM}$ has been decreasing in all societies in the last 30 years $(16,17)$.

Two risk factors detected in CHM development are advanced or early maternal age and previous molar pregnancy $(18,19)$. When compared to women aged between 21-35, women older than 35 and younger than 21 have a 1.9-fold increase in risk of CHM. Women older than 40, experience a 7.5 -fold increase in risk $(18,19)$. Risk of HM pregnancy following another HM pregnancy is more than $10-20$-fold higher depending on the society $(20,21)$. Another risk factor for HMs is spontaneous abortion history. This situation poses a risk of HM pregnancy of more than 2-3fold higher depending on the society (22). Moreover, the age of menarche, parity, the time between previous pregnancies, genetic factors, malnutrition, viral infections and low socio-economic level provide predisposition for gestational trophoblastic diseases (GTD) (23). It is also detected that there is a reverse relationship between $\mathrm{HM}$ and the existence of $\beta$-carotene and animal-fat in the diet $(24,25)$.
In this study, we aim to compare Syrian immigrant and Turkish pregnant women in terms of HM incidence in endometrial curettage materials performed due to abortion and termination of pregnancy in a tertiary hospital.

\section{METHOD}

Ethics committee approval for the study was obtained from the ethics committee for clinical research of our institution. Pathology reports of 907 endometrial curettage materials performed due to abortion or termination of pregnancy between the years 2016-2018 were digitally analyzed. Cases were evaluated retrospectively in light of the information obtained from pathology reports. Cases were classified as Syrian or Turkish. Cases with HM were compared in terms of age and incidence of the disease.

Curettage materials submitted to our pathology laboratory due to abortion or termination of pregnancy were examined with routine histopathologic methods (Hematoxylin \& Eosin staining). Examination of the curettage materials was repeated by a pathologist to confirm the diagnosis.

In light of the histopathological findings described below, we diagnosed HM (partial or complete).

Microscopic examination shows a mixture of two villus populations consisting of small, fibrotic and normal-looking villi with large, irregularly shaped, slightly synsityotrophoblastic hyperplasia followed by hydropic villi in partial HM (Image 1). In some large villi, cisternae (cavitation) can be seen, while other large villi appear dysmorphic with their irregular scalloped complex contours and their

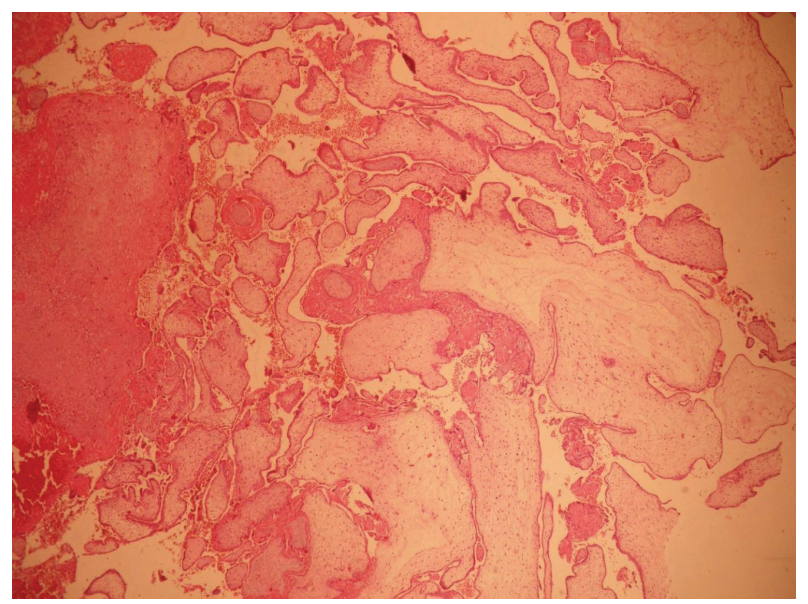

Image 1: Microscopic examination shows a mixture of two villus populations consisting of small, fibrotic and normal-looking villi in partial HM and large, irregularly shaped, slightly synsityotrophoblastic hyperplasia followed by hydropic villi. Cisterns (cavitation) can be seen in some large villi, while other large villi appear dysmorphic with their irregular scalloped complex contours and their invaginations and inclusions paved with trophoblasts. 10X H\&E. 
invaginations and inclusions paved with trophoblasts (Image 1 and 2). Generally, mild villous and chorionic plate trophoblast (predominantly synsityotrophoblastic) hyperplasia is seen. There is usually no apparent cytological atypia in trophoblasts. They also often contain fetal erythrocytes with villous blood vessels nucleus. Other evidence of fetal development (embryonic or fetal tissue, chorionic membrane, amnion, yolk sac, and umbilical cord) can also be seen.

In complete HM, the lesion consists entirely of large, hydropic and often cisternal villi. In addition, the common trophoblast layers that combine one or more villi and encircle the villi are also a distinct finding. The concentric distribution of this villous trophoblastic proliferation to some villi and the formation of both cytotrophoblasts and syncytiotrophoblasts is also a remarkable finding.

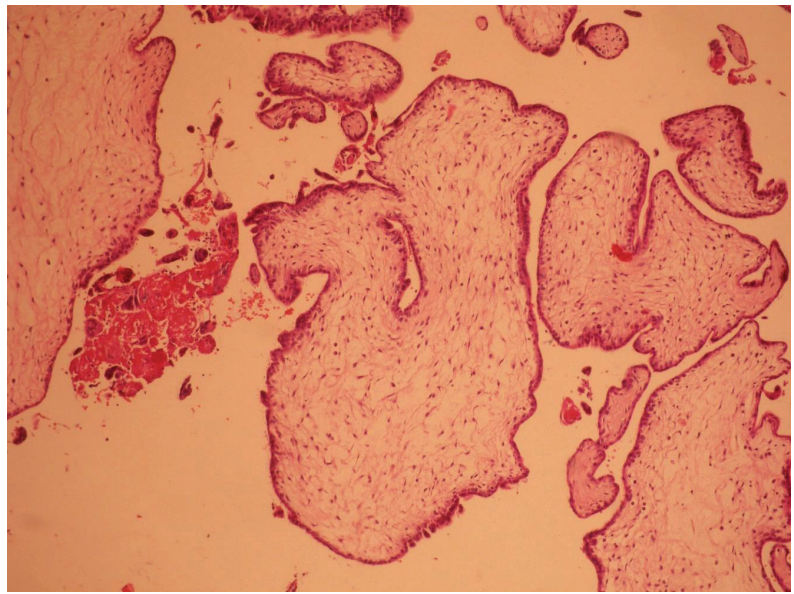

Image 2: Partial HM, large scalloped contoured villi with trophoblasts with paved invaginations and one inclusion. 10X H\&E.

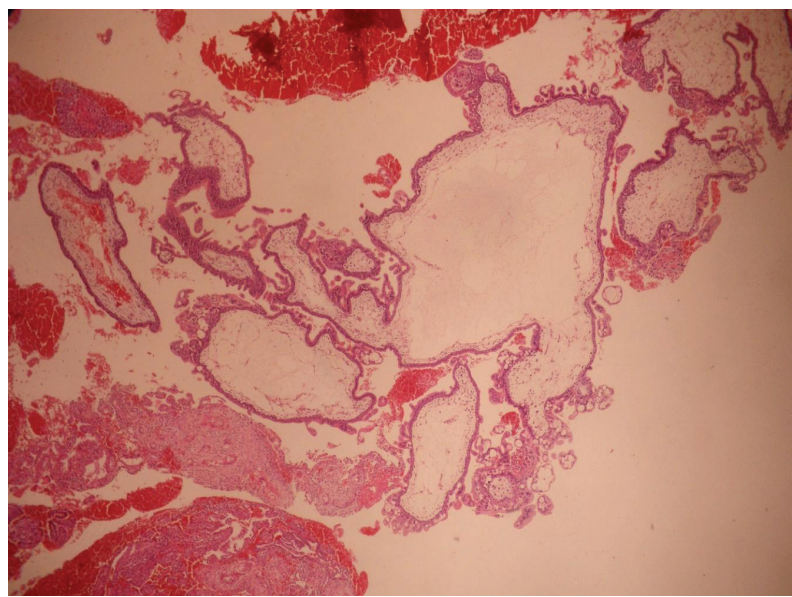

Image 3: Complete HM, completely large, cavitation and circumferential trophoblastic hyperplasia of villi consisting of lesions. 10X H\&E.
Usually, syncytiotrophoblasts may appear immature and form Medusa-like festoons that emerge from molar villi (Image 3). There is also a marked trophoblastic atypical especially in the decidual implantation area (Image 4). Non-villous gestational tissues (embryonic or fetal tissue, chorionic membrane, amniotic, yolk sac, and umbilical cord) and fetal erythrocytes with nucleus are typically absent. Despite all these histopathological findings, in some early cases, the complete HM may be confused with partial HM. P57 immunohistochemical examination may be useful in this distinction. Nuclear staining is seen in trophoblasts that lay villi in partial HM, while no staining is seen in complete HM (Image 5).

Normal distribution suitability of variables was analyzed with the Shapiro Wilk test. Age as a result of the normality test is expressed as mean \pm standard deviation and

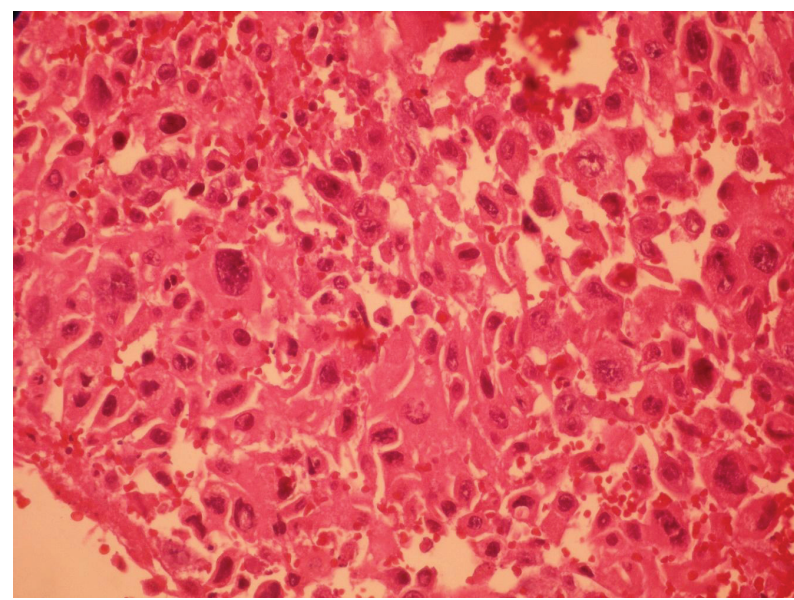

Image 4: Prominent trophoblastic atypical histology in complete hydatidiform mole. 40X H\&E.

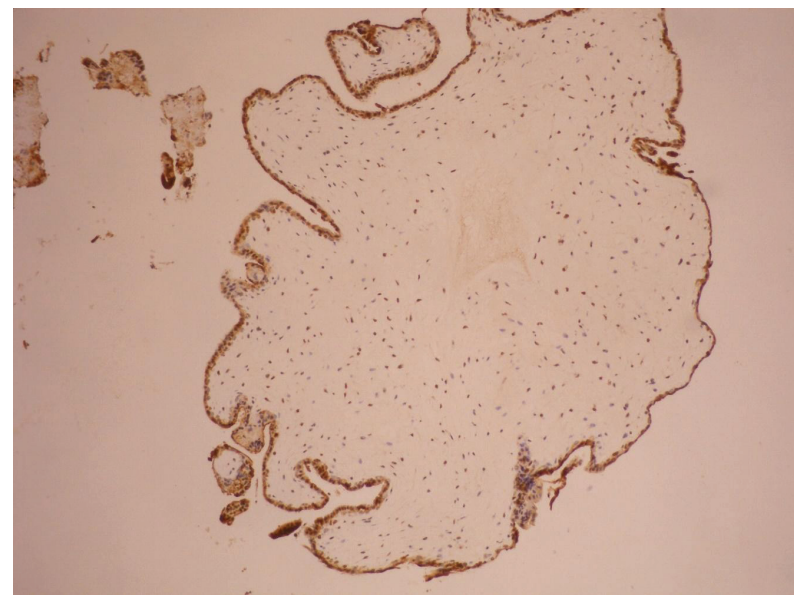

Image 5: Widespread and strong nuclear staining with p57KIP-2 is observed in trophoblasts in the villus containing a small cavitation with a large scalloped contour in the partial hydatidiform mole. 10X p57KIP-2. 
(minimum: maximum) values. Categorical variables are expressed with $\mathrm{n}(\%)$. The unpaired t-test was used in the comparison of age between HM groups. The Pearson chi-square test was used for comparisons of categorical variables among groups. Independent risk factors considered to be effective in HM detection were analyzed with binary logistic regression analysis. SPSS (IBM Corp. Released 2012. IBM SPSS Statistics for Windows, Version 21.0. Armonk, NY: IBM Corp.) The program was used for statistical analysis and $p<0.05$ was accepted as statistically significant.

\section{RESULTS}

The arithmetic mean age of the 907 pregnant women who underwent curettage due to abortion or termination of pregnancy was 29.64 (ranging between 13-54).

HM was diagnosed in 78 of 907 pregnant women (8.59\%) who underwent curettage due to abortion or termination of pregnancy. 768 of these 907 pregnant women were Turkish (84.67\%) and 139 of them were Syrian immigrants (15.33\%) (Table 1). HM was diagnosed in 56 of 768 Turkish pregnant women (7.30\%) and in 22 of 139 Syrian immigrant pregnant women (15.80\%). There was a significant difference between Turkish women and Syrian immigrant women in terms of HM incidence $(p=0.001)$.

Between the years 2016-2018, 33,108 live births took place in our hospital. 25,764 of these (77.82\%) were Turkish and 7, 344 were Syrian (22.18\%). HM was diagnosed in curettage of 56 Turkish women out of 768 and in 22 Syrian women out of 139. According to this result, the total HM incidence between the years 2016-2018 among all pregnant women was 2.29 per thousand (78/34 015), HM inci- dence in Turkish pregnant women was 2.11 per thousand (56/26 532) and in Syrian pregnant women it was 2.93 per thousand (22/7 483) and the difference between groups was not statistically significant $(p=0.185)$.

While the arithmetic mean age of the 768 Turkish pregnant women was $30.41 \pm 6.83$, the arithmetic mean age of 139 Syrian immigrant pregnant women was 25.40 7.22 . The arithmetic mean age of the HM diagnosed 78 pregnant women was calculated as $27.94 \pm 8.07$ (Table 1). HM frequency was higher in the group with age less than 20 compared to the group with age 35-39 (Figure 1). The arithmetic mean age of the HM diagnosed 56 Turkish pregnant women was $29.61 \pm 7.87$ and the arithmetic mean age of the HM diagnosed 22 Syrian immigrant pregnant women was $23.18 \pm 6.71$. The rate of Syrian pregnant women in the group aged younger than 20 was significantly higher $(p<0.001)$. Similarly, the rate of Syrian pregnant women was also high in the group aged 20 $24(p=0.001)$. There was no significant difference in the group aged 25-29 $(p=0.399)$. The rate of Turkish pregnant women was high in the group aged 30-34 ( $<<0.001)$. The rate for Turkish women was also high in the group aged 35-39 ( $p=0.032)$. The rate for Turkish women was also high in the group aged $\geq 40$ years $(p=0.035)$. The age dis-

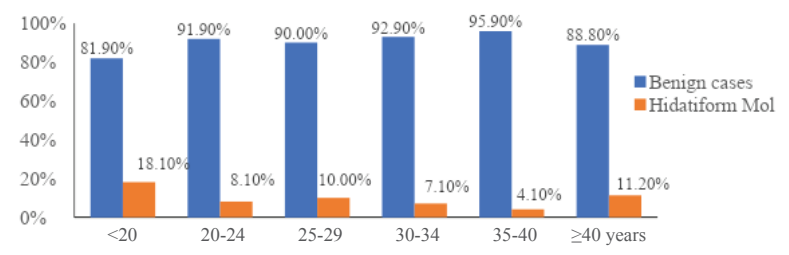

Figure 1: Age distribution of hydatidiform mole cases.

Table 1: Comparisons between hydatidiform mole and benign groups.

\begin{tabular}{|c|c|c|c|}
\hline & Benign cases $(n=829)$ & Hydatidiform mole $(n=78)$ & p-value \\
\hline \multicolumn{4}{|l|}{ Nationality } \\
\hline Turkish & $712(92.70 \%)$ & $56(7.30 \%)$ & $0.001^{a}$ \\
\hline Syrian & $117(84.20 \%)$ & $22(15.80 \%)$ & \\
\hline Age & $29.81 \pm 7.01(13: 54)$ & $27.94 \pm 8.07(14: 47)$ & $0.017^{b}$ \\
\hline \multicolumn{4}{|l|}{ Age group } \\
\hline$<20$ years & $59(81.90 \%)$ & $13(18.10 \%)$ & $0.013^{a}$ \\
\hline 20-24 years & $158(91.90 \%)$ & $14(8.10 \%)$ & \\
\hline 25-29 years & $181(90 \%)$ & $20(10 \%)$ & \\
\hline 30-34 years & $197(92.90 \%)$ & $15(7.10 \%)$ & \\
\hline 35-39 years & $163(95.90 \%)$ & $7(4.10 \%)$ & \\
\hline$\geq 40$ years & 71 (88.80\%) & $9(11.30 \%)$ & \\
\hline
\end{tabular}

Data is given as $\mathrm{n}(\%)$ and mean \pm standard deviation (minimum: maximum).

a: Pearson chi-square test, b: Independent samples t test.

Percentages given in the table are reported according to the variables in the rows. 


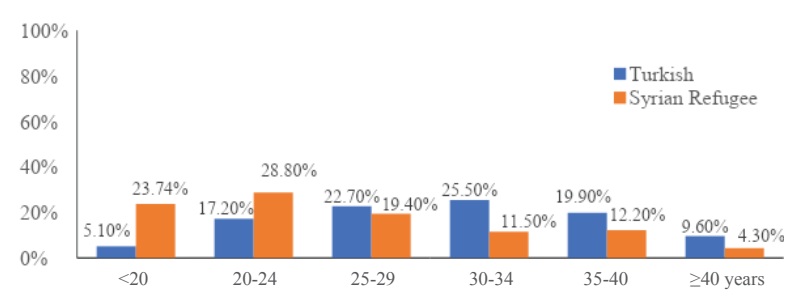

Figure 2: Age distribution of Turkish and Syrian immigrant pregnant women who underwent curettage.

tribution of Turkish and Syrian immigrant pregnant women who underwent curettage is shown in Figure 2.

Risk factors affecting HM occurrence is shown in Table 2. Nationality was found to be a risk factor in HM determination and the risk was 2.06 times higher in Syrian than Turkish women. Presence in the group aged 35-39 years was detected as a protective factor with respect to the group aged $<20$ years. Presence in the group aged 35-39 years reduced the risk of $\mathrm{HM}$ detection at a rate of $74 \%$.

Table 2: Risk factors affecting hydatidiform mole occurrence.

\begin{tabular}{lccc}
\hline $\begin{array}{l}\text { Risk Factor } \\
\text { Age Group }\end{array}$ & Wald & OR $(95 \% \mathrm{Cl})$ & p-value \\
$\quad<20$ (Ref. Cat) & - & - & - \\
$20-24$ & 3.14 & $0.47(0.21: 1.08)$ & 0.076 \\
$25-29$ & 1.20 & $0.64(0.29: 1.42)$ & 0.274 \\
$30-34$ & 3.15 & $0.47(0.20: 1.08)$ & 0.076 \\
$35-39$ & 7.16 & $0.26(0.10: 0.70)$ & $\mathbf{0 . 0 0 7}$ \\
$\geq 40$ & 0.26 & $0.78(0.30: 2.03)$ & 0.609 \\
Nationality & & & \\
$\quad$ Turkish (Ref. Cat.) & - & - & - \\
$\quad$ Syrian & 6.14 & $2.06(1.16: 3.64)$ & $\mathbf{0 . 0 1 3}$ \\
\hline
\end{tabular}

Logistics regression model was significant $(p=0.004)$

OR: Odds ratio, Cl: Confidence interval, Ref. Cat: Reference category

\section{DISCUSSION}

At the end of this study, the incidence of HM in curettage materials performed due to abortion or termination of pregnancy in 768 Turkish pregnant women was $7.30 \%$. This value is in conformity with previous studies performed in Turkey. The incidence of HM in curettage materials performed due to abortion or termination of pregnancy in $139 \mathrm{immigrant}$ pregnant women was $15.80 \%$. Statistically, the HM incidence in Syrian immigrant pregnant women was significantly higher (2.06 times) than Turkish women. The arithmetic mean age of Syrian pregnant women was lower than that of Turkish pregnant women. Age and nationality were detected as risk factors for HM.
In the literature, the incidence of $\mathrm{HM}$ is usually given over the number of pregnancies, but the incidence in curettage materials due to abortion or termination of pregnancy has been analyzed less. We could find only three research studies in the literature that examined $\mathrm{HM}$ incidence in curettage materials due to abortion or termination of pregnancy. Biscaro et al. found the HM incidence in Brazilian pregnant women who underwent curettage due to abortion or termination of pregnancy to be $2.24 \%$ (10 HM in 446 curettage materials) (12). In our study, the incidence of HM in Turkish pregnant women in our country who underwent curettage due to abortion or termination of pregnancy was 3.3 times higher than Brazilian women. However, in Germany, in the study performed by Horn et al. (27), the incidence of HM in curettage materials due to abortion or termination of pregnancy in German pregnant women was $5.1 \%$. In the study performed by Mulisya et al. in Uganda (25), the incidence of HM in Ugandan (sub-Saharan Africa) pregnant women was 6.1\% (11 HM in 118 curettage materials) and in the study performed by Adalı et al. in Turkey (3), the incidence of HM in Turkish pregnant women in the Kars province was $6.9 \%$ (19 HM in 277 curettage materials).

The aim of this study was to compare the HM incidence in curettage materials due to abortion or termination of pregnancy in Syrian immigrant pregnant women and Turkish pregnant women. At the end of the study, it was found that the incidence of $\mathrm{HM}$ in curettage materials due to abortion or termination of pregnancy in Syrian immigrant pregnant women was significantly higher than Turkish pregnant women. The fact that pregnancy in adolescence is approximately 5 times higher in Syrian immigrant women explains the high HM incidence. Besides this, stress (war and migration), low socio-economic level and probable infections that may occur due to these factors may have contributed to this increase in $\mathrm{HM}$ incidence. The effect of these variables on the incidence of HM in immigrants should be analyzed in future studies.

The likelihood of many more induced abortions in Turkish pregnant women should not be overlooked during the assessment of the data. Despite the fact that both societies are Muslim, induced termination of pregnancy in curettages under 10 weeks may cause a decrease in the $\mathrm{HM}$ rate in Turkish pregnant women.

An important limitation of the study is that this was a mono-centre study. What is the situation in other hospitals in the province of Bursa? What is the situation in private hospitals? Further research studies are necessary on these issues. Another limitation is that this was a retrospective study. For this reason, probable causes that may affect HM could not be interrogated.

In conclusion, this is the first study that investigated the incidence of HM in Syrian immigrant pregnant women. In our 
region, the incidence of $\mathrm{HM}$ in Syrian immigrant pregnant women was significantly higher than Turkish pregnant women. Major probable causes that may affect HM incidence in Syrian immigrant pregnant women are nationality and age. The effect of factors such as socio-economic level, nutrition, infection, stress and exposure to conditions of warfare on this situation should be analyzed in further studies.

Ethics Committee Approval: Bursa Higher Specialization Training and Research Hospital, Clinic Researches Ethical Committee Number: 2011-KAEK-25 2018/11-25.

Informed Consent: Written consent was obtained from the participants.

Peer Review: Externally peer-reviewed.

Author Contributions: Conception/Design of Study- T.E., H.D..; Drafting Manuscript- T.E., H.D..; Final Approval and Accountability- T.E., H.D.

Conflict of Interest: Authors declared no conflict of interest.

Financial Disclosure: Authors declared no financial support.

Etik Komite Onayı: Bursa Yüksek İhtisas Eğitim ve Araştırma Hastanesi Klinik Araştırmalar Etik Kurulu Numara: 2011-KAEK-25 2018/11-25.

Bilgilendirilmiş Onam: Katılımcılardan bilgilendirilmiş onam alınmıştır.

\section{Hakem Değerlendirmesi: Dış bağımsız.}

Yazar Katkıları: Çalışma Konsepti/Tasarım- T.E., H.D.; Yazı Taslağı- T.E., H.D..; Son Onay ve Sorumluluk- T.E., H.D.

Çıkar Çatışması: Yazarlar çıkar çatışması beyan etmemişlerdir.

Finansal Destek: Yazarlar finansal destek beyan etmemişlerdir.

\section{REFERENCES}

1. Mülteciler Derneği. Türkiyedeki Suriyeli Sayısı. Available from: URL: https://multeciler.org.tr/turkiyedeki-suriyelisayisi/ Access Date: 22.05.2019.

2. Anadolu Ajansı. Türkiye'de doğan Suriyeli bebek sayısı açıklandı. Available from: https://www.aa.com.tr/tr/turkiye/ turkiyede-dogan-suriyeli-bebek-sayisi-aciklandi/1144564. Access Date: 22.05.2019.

3. Seckl MJ, Sebire NJ, Berkowitz RS. Gestational trophoblastic disease. Lancet 2010;376(9742):717-29. [CrossRef]

4. Adalı Y, Eroğlu HA, Güvendi GF, Deniz R, Baykuş Y. Frequency of hydatidiform mole in curettage material between 2014 and 2016 in a university hospital. Med Sci 2018;13(3):66-71. [CrossRef]

5. Lurain JR. Gestational trophoblastic disease I: epidemiology, pathology, clinical presentation and diagnosis of gestational trophoblastic disease, and management of hydatidiform mole. Am J Obstet Gynecol 2010;203(6):531-9. [CrossRef]
6. Curry SL, Hammond CB, Tyrey L, Creasman WT, Parker RT. Hydatidiform mole: diagnosis, management, and long-term follow up of 347 patients. Obstet Gynecol 1975;45(1):1-8. [CrossRef]

7. Kohorn El. Molar pregnancy: presentation and diagnosis. Clin Obstet Gynecol 1984;27:181-9. [CrossRef]

8. Soto-Wright V, Bernstein M, Goldstein DP, Berkowitz RS. The changing clinical presentation of complete molar pregnancy. Obstet Gynecol 1995;86(5):775-9. [CrossRef]

9. Hou JL, Wan XR, Xiang Y, Qi OW, Yang XY. Changes of clinical features in hydatidiform mole: analysis of 113 cases. J Reprod Med 2008;53(8):629-33.

10. Czernobilsky B, Barash A, Lancet M. Partial moles: a clinicopathologic study of 25 cases. Obstet Gynecol 1982;59:75-7.

11. Szulman $A E$, Surti U. The clinicopathologic profile of the partial hydatidiform mole. Obstet Gynecol 1982;59:597602.

12. Berkowitz RS, Goldstein DP, Bernstein MR. Natural history of partial molar pregnancy. Obstet Gynecol 1985;66:677-81.

13. Biscaro A, Silveira SK, Locks GD, Mileo LR, Silva Júnior JP, Pretto P. Frequency of hydatidiform mole in tissue obtained by curettage. Rev Bras de Ginecol Obstet 2012;34(6):254-8.

14. Mbamara SU, Obiechina NJ, Eleje GU, Akabuike CJ, Umeononihu OS. Gestational trophoblastic disease in a tertiary hospital in Nnewi, southeast Nigeria. Niger Med J 2009;50(4):87

15. Moodley M, Tunkyi K, Moodley J. Gestational trophoblastic syndrome: an audit of 112 patients. A South African experience. Int J Gynecol Cancer 2003;13(2):234-9. [CrossRef]

16. Brinton LA, Bracken MB, Connelly RR. Choriocarcinoma incidence in the United States. Am J Epidemiol 1986;123:1094-100. [CrossRef]

17. Smith HO, Qualls CR, Prairie BA, Padilla LA, Rayburn WF, Key CR. Trends in gestational choriocarcinoma: a 27-year perspective. Obstet Gynecol 2003;102(5):978-87. [CrossRef]

18. Parazzini F, LaVecchia C, Pampallona S. Parental age and risk of complete and partial Hydatidiform mole. Br J Obstet Gynecol 1986;93:582-5. [CrossRef]

19. Sebire NJ, Foskett M, Fisher RA, Rees $H$, Seckl M, Newlands E. Risk of partial and complete hydatidiform molar pregnancy in relation to maternal age. BJOG 2002;109(1):99-102. [CrossRef]

20. Sand PK, Lurain JR, Brewer JI. Repeat gestational trophoblastic disease. Obstet Gynecol 1984;63(2):140-4.

21. Berkowitz RS, Im SS, Bernstein MR, Goldstein DP. Gestational trophoblastic disease: Subsequent pregnancy outcome, including repeat molar pregnancy. J Reprod Med 1998; 43:81-6.

22. Parazzini F, Mangili GI, La CV, Negri E, Bocciolone L, Fasoli M. Risk factors for gestational trophoblastic disease: a separate analysis of complete and partial hydatidiform moles. Obstet Gynecol 1991;78(6):1039-45.

23. Ghaemmaghami F, Ashraf-Ganjooie T. Gestational trophoblastic neoplasia. Asia Pac J Clin Oncol 2006;2(1):921. [CrossRef]

24. Berkowitz RS, Cramer DW, Bernstein MR, Cassells S, Driscoll SG, Goldstein DP. Risk factors for complete molar pregnancy from a case-control study. Am J Obstet Gynecol 1985;152(8):1016-20. [CrossRef] 
25. Parazzini F, La Vecchia C, Mangili G, Caminiti C, Negri E, Cecchetti G, Fasoli M. Dietary factors and risk of trophoblastic disease. Am J Obstet Gynecol 1988;158(1):939. [CrossRef]

26. Horn LC, Rosenkranz M, Bilek K. The value of placental histology for the detection of genetically-induced abortions. Z Geburtshilfe Perinatol 1991;195(2):47-53.
27. Mulisya O, Roberts DJ, Sengupta ES, Agaba E, Laffita D, Tobias T, Mpiima DP, Henry L, Augustine S, Abraham M, Hillary T. Prevalence and Factors Associated with Hydatidiform Mole among Patients Undergoing Uterine Evacuation at Mbarara Regional Referral Hospital. Obstet Gynecol Int 2018;2018:9561413. [CrossRef] 